\title{
Assessment of acute toxicity profile of Lasianthera africana leaf extract in normal rats and its ameliorative effect in alloxan-induced diabetic rats
}

\author{
U. E. Inyang ${ }^{1 \star}$, P. A. Nwafor ${ }^{2}$ and U. N. Asamudo ${ }^{3}$ \\ ${ }^{1}$ Department of Food Science and Technology, University of Uyo, Uyo, Akwa Ibom State, Nigeria. \\ ${ }^{2}$ Department of Pharmacology and Toxicology University of Uyo, Uyo, Akwa Ibom State, Nigeria. \\ ${ }^{3}$ Department of Microbiology University of Uyo, Uyo, Akwa Ibom State, Nigeria.
}

Received 11 September, 2014; Accepted 25 March, 2015

\begin{abstract}
The present study evaluated the acute toxicity effect of Lasianthera africana leaf extract on normal rats and effect of the extract on the hepatic and renal function indices in alloxan-induced diabetic rats. In the acute toxicity test, male Wister rats received orally four different single dose of the extract and were kept under observation for 14 days. The result indicates that $L D_{50}$ of the extract is higher than 5,000 $\mathrm{mg} / \mathrm{kg}$ body weight. For the second experiment, doses $(50,100$ and $200 \mathrm{mg} / \mathrm{kg}$ body weight) of the leaf extract were administered orally to alloxan-induced diabetic rats for 28 days and the effect of the treatment on blood glucose, hepatic enzymes, serum proteins and renal function indices was evaluated. The result indicates progressive and significant $(p>0.05)$ reduction in fasting blood glucose. The extract also exhibited significant $(p<0.05)$ reduction in serum aspartate aminotransferase (AST), alanine transaminase (ALT) and alkaline phosphatase $(A L P)$, and significant $(p<0.05)$ increase in serum total proteins and globulin and marginal $(p>0.05)$ reduction in serum creatinine and uric acid relative to the diabetic control group. The results suggest that the leaf extract is safe and may be beneficial in the management of diabetic mellitus.
\end{abstract}

Key words: Lasianthera africana leaf, acute toxicity, hepatotoxicity, renal function indices.

\section{INTRODUCTION}

The revelation of toxicity profile of plant products intended for use as a source of nutrients and non-nutrient health benefiting phytochemicals helps in the determination of the extent of its safety. This is because as important as it is for a product to be efficiently cheap and readily available, there is extreme need for such product to be safe for short and long term uses. The World Health Organization (WHO) has emphasized the fact that safety should be the over-riding criterion in the selection of herbal medicine for use in health care delivery (WHO, 1980). According to Lorke (1983), investigation of acute toxicity is the first step in the toxicological investigation of an unknown substance. The index of acute toxicity is the lethal dose $50\left(L_{50}\right)$. It is usually carried out on rats or mice by oral, intraperitoneal, intravenous or intramuscular routes of administration (Homburger, 1989). According to Homburger

${ }^{*}$ Corresponding author. E-mail: inyang.ufot@yahoo.com.

Author(s) agree that this article remains permanently open access under the terms of the Creative Commons Attribution License $\underline{4.0 \text { International License }}$ 
(1989), $L D_{50}$ values should be reported in terms of the duration over which the animals were observed. The period may range from $24 \mathrm{~h}$ to 14 days or longer.

Lasianthera africana ( $P$. Beauv) is one of the top six green leafy vegetables commonly consumed by the Efik and Ibibio ethnic groups in Nigeria (Williams et al., 2009). It belongs to the family Icacinaceae. The plant is called "editan" in Efik and Ibibio local dialects of Nigeria. It is a perennial, glabrous, shrub that reaches a height of 61 to $136 \mathrm{~cm}$ (Hutchinson and Dalziel, 1973). Among the Ibibios, four local varieties based on the leaf colour, taste and habitat are known. The varieties are the "afia", "akai", "idim", and "obubit" (Bassey et al., 2006). Traditionally, the leaves are utilized for both food and therapeutic purposes. The consumption of the leaf is high among rural communities where it is mostly found especially during the period that other leafy vegetables are out of season. It therefore plays a significant role in household food security. From prehistoric time, the plant has been exploited by traditional herbalists for the treatment of various ailments including typhoid fever, diarrhoea and candidiasis among other ailments (Andy et al., 2008). Ebana et al. (1996) reported that the leaf of $L$. africana is rich in chemical compounds of nutritional and therapeutic importance. Sofowora (1989) reported that the leaves are highly nutritive and are used in traditional concoctions for the treatment of ailments like constipation and general stomach aches. Aqueous extract of the leaf is usually taken orally or in enama form to treat indigestion, stomach discomfort and internal heat (Etukudo, 2003). According to Bassey et al. (2006), substantial levels of alkaloids, flavonoids, terpenes, anthraquiniones, phlobatannins, cardiac glycosides, saponins and tannins occur in the leaf. The presence of health promoting and protecting compounds such as alkaloids and flavonoids suggests that the leaf could be used to manage diabetes mellitus that is prevalence in our societies today.

Notwithstanding, the long term use of $L$. africana leaf and leaf products in soup preparation and traditional concoctions, there is dearth of scientific information on its toxicity profile. This study was therefore designed to assess the acute toxicity level of $L$. africana leaf extract in normal rats and the ameliorative effect of the extract in alloxan- induced diabetic rats.

\section{MATERIALS AND METHODS}

Twigs of white variety ("afia") of $L$. africana leaves were harvested from a garden at Aka Offot in Uyo, Akwa Ibom State, Nigeria and authenticated at the Taxonomy Unit of the Department of Botany and Ecological Sciences, University of Uyo, Nigeria. The leaves were destalked, washed in potable water, spread to surface air dry and cut $(2 \mathrm{~mm}$ width). The cut leaf was blended with water $(1: 3 \mathrm{w} / \mathrm{v})$ using Kenwood blender (Kenwood Ltd., Havant, UK). The blend was left for $2 \mathrm{~h}$ at room temperature $\left(26 \pm 2^{\circ} \mathrm{C}\right)$ before filtering through $425 \mu \mathrm{m}$ pore size sieve. The filtrate was stored at $4^{\circ} \mathrm{C}$ for subsequent use. A known volume of the filtrate was evaporated to dryness in a conventional oven (model P.P.22US, Genlab, England) and the weight of the residue was used to determine the concentration of the filtrate which was in turn used to determine the dose of administration of the extract (Achukwu et al., 2009; Ikewuchi and Ikewuchi, 2012).

\section{Animal procurement and care}

Three months old male albino rats weighing between 148 and 161 $\mathrm{g}$ obtained from the Animal Breeding Unit, Faculty of Basic Medical Sciences, University of Uyo, Akwa lbom State, Nigeria were used for the experiment. Animals were housed in well ventilated stainless steel cages containing wood shavings for bedding. The animals were allowed to acclimatize for 7 days and maintained with standard grower's mash (UAC Vital Feed produced by Grand Cereals, Jos, Nigeria) and tap water ad libitum prior to experimenttation. Animals were maintained under normal environmental temperature $\left(26 \pm 2^{\circ} \mathrm{C}\right)$ with normal $12: 12 \mathrm{~h}$ dark/light cycle. The room was cleaned and disinfected regularly. Soiled wood shavings were replaced weekly. The feed and water containers were also washed regularly. Each rat was marked for identification. The experiments were conducted in accordance with the internationally accepted principles for Laboratory Animal use and care as found in the US guidelines (NIH publication No. 85-23, revised in 1985).

\section{Acute toxicity $\left(L_{50}\right)$ studies}

The acute toxicity profile of the leaf extract was determined using the method described by Lorke (1983). Healthy male albino rats weighing between 148 and $160 \mathrm{~g}$ were randomly divided into five groups of five rats per group. The rats were deprived of food but allowed access to water ad libitum for $16 \mathrm{~h}$ prior to the administration of the leaf extract on day zero. The extract was administered orally at doses of $500,1000,3000$ and $5,000 \mathrm{mg} / \mathrm{kg}$ body weight to determine the range within which toxicity lie. Rats in control group received no extract. All rats were monitored immediately after dosing and at intervals of $2 \mathrm{~h}$ for a total period of $12 \mathrm{~h}$ for signs of toxicity such as excitement, ataxia, alertness, nervousness and dullness. For the remaining of the 14 days study period, animals were monitored daily for mortality and signs of toxicity. Animal's body weight was measured prior to dosing on day 0 and on day 14. The number of survivors after the 14 day period was noted. On the last day, animals were sacrificed and the macroscopic evaluation of the liver and kidney was carried out to access the gross effect on the morphological features and appearance of the organs. The lethal dose $\left(L D_{50}\right)$ was assessed on the bases of mortality (Angelis Pereira et al., 2005).

\section{Inducement of diabetes}

Alloxan monohydrate (Sigma-Aldrich Co., USA) was used to induce diabetes mellitus in normoglycaemic rats. Animals were allowed to fast for $16 \mathrm{~h}$ and were injected intraperitonially (i.p) with freshly prepared alloxan monohydrate in distilled water in a dose of 150 $\mathrm{mg} / \mathrm{kg}$ body weight (Antai et al., 2010). Initial blood glucose was determined prior to inducement with alloxan and after 7 days of inducement to confirm diabetic state of the rats. Blood was collected from the tip of tail vein for glucose determination. Rats that showed fasting blood glucose levels above $230 \mathrm{mg} / \mathrm{dl}$ were selected for the study.

\section{Experimental protocol}

Twenty-five (25) alloxan-induced diabetic male albino rats were divided into five groups (groups 2-6) of five rats per group. Rats in group 1 (normal control) were given feed and drinking water only for 
Table 1. Effect of oral administration of doses of Lasianthera africana leaf extract on body weight of normal rat after 14 days.

\begin{tabular}{cccc}
\hline $\begin{array}{c}\text { Dose levels } \\
\text { (mg/kg body weight) }\end{array}$ & $\begin{array}{c}\text { Initial weight (g) } \\
\text { (day 0) }\end{array}$ & $\begin{array}{c}\text { Final weight (g) } \\
\text { (day 14) }\end{array}$ & $\begin{array}{c}\text { Weight gain } \\
\text { (\%) }\end{array}$ \\
\hline 0.00 & $159.00^{\mathrm{b}} \pm 3.61$ & $173.00^{\mathrm{a}} \pm 2.00$ & 9.01 \\
500 & $148.33^{\mathrm{b}} \pm 2.08$ & $164.00^{\mathrm{a}} \pm 4.00$ & 10.56 \\
1.000 & $157.00^{\mathrm{b}} \pm 2.00$ & $170.33^{\mathrm{a}} \pm 4.51$ & 8.49 \\
3.000 & $152.00^{\mathrm{b}} \pm 2.65$ & $164.00^{\mathrm{a}} \pm 2.65$ & 7.89 \\
5.000 & $160.67^{\mathrm{b}} \pm 3.51$ & $173.00^{\mathrm{a}} \pm 3.00$ & 7.67 \\
\hline
\end{tabular}

Values are means $\pm S D, n=5$. Means on the same row with different superscripts are significantly different at $\mathrm{p}<0.05$.

28 days. Rats in group 2 (diabetic control) were also given feed and drinking water only for 28 days. Rats in group 3 were given feed, drinking water and treated with metformin (anti-diabetic drug) at a dose level of $100 \mathrm{mg} / \mathrm{kg}$ body weight daily (Tang et al., 2006) for 28 days. Rats in groups 4, 5 and 6 were treated daily with doses (50, 100 and $200 \mathrm{mg} / \mathrm{kg}$ body weight), respectively, of $L$. africana leaf extract for 28 days. They also had access to feed and drinking water ad libitum for the 28 days. The extract was given to the rats by oral administration using canula. The first day of administration was taken as day zero while the sacrifice day was on day 28 . Fasting blood glucose was measured on the 0,7, 14, 21 and 28 day of treatment. At the end of the treatment, animals were fasted overnight, but allowed access to water ad libitum. The rats were euthanized and ex-sanguinated under chloroform anaesthesia and their blood collected by jugular vein puncture (Wilson et al., 2001). The blood samples were dispensed into sterile plain tubes, allowed to stand for $3 \mathrm{~h}$ at room temperature $\left(26^{\circ} \mathrm{C}\right)$ to ensure complete clotting and centrifuged at $3500 \mathrm{rpm}$ for $10 \mathrm{~min}$. The clear sera were aspirated off and stored at $-20^{\circ} \mathrm{C}$ for biochemical evaluation.

\section{Methods of analysis}

Fasting blood glucose (FBG) was measured by single touch glucometer (One Touch Ultra 2 Blood Glucose Monitoring System, Lifescan Inc., Milpitas, USA). The weight of each rat was measured using Ohaus Electronic Weighing balance (Model CS 2000, USA). Biochemical indices were determined using standard ready-to-use reagent kits, (Randox Ltd., UK) following the manufacturer's instructions. The indices determined included aspartate aminotransferase (AST), alanine aminotransferase (ALT), alkaline phosphatase (ALP), total proteins, albumin, creatinine and uric acid.

\section{Statistical analysis}

The results of the studies were expressed as mean \pm SD (standard deviation) of triplicate determinations. The data obtained were subjected to One-way Analysis of Variance (ANOVA) using SPSS version 18 statistical software package (SPSS, Inc., USA) to determine variation between treatments. Post hoc test was done using Tukeys test for multiple comparisons. Significant variation was accepted at $p<0.05$.

\section{RESULTS}

\section{Acute toxicity studies}

L. africana leaf extract administered by oral route at doses up to $5,000 \mathrm{mg} / \mathrm{kg}$ body weight (single dose) did not produce any sign of toxicity or death in rats during 14 days of observation. Adverse clinical symptoms or toxicity signs like vomiting, diarrhoea, nervousness, ataxia and anorexia were not observed in the rats during the period of observation. Each treatment group exhibited significant $(p<0.05)$ increase in body weight on the 14 th day relative to the initial weight (Table 1). The percentage weight gained ranged from $7.67 \%$ for rats treated with 5,000 $\mathrm{mg} / \mathrm{kg}$ to $10.56 \%$ for rats treated with $500 \mathrm{mg} / \mathrm{kg}$ body weight of the extract. Macroscopic examination of the livers and kidneys showed no discoloration, shrinkage, holes or other signs of abnormality.

\section{Effect of aqueous extract on fasting blood glucose (FBG) in alloxan-induced diabetic rats}

Table 2 shows the effect of oral administration of doses of $L$. africana leaf extract on the fasting blood glucose in alloxan-induced diabetic rats. Alloxan-induced diabetic rats had significantly $(p<0.05)$ higher fasting blood glucose compared to that of normal control rats. The result indicated that the fasting blood glucose level of the normal control rats varied marginally while diabetic control rats showed progressive increase $(p<0.05)$ in fasting blood glucose level throughout the 28 days period. The result of average weekly measurement of the fasting blood glucose revealed that daily treatment (oral administration) of diabetic rats with doses (50, 100 and $200 \mathrm{mg} / \mathrm{kg}$ body weight) of $L$. africana leaf extract resulted in significant $(p<0.05)$ reduction in the fasting blood glucose. Compared with the glucose level before treatment (day 0), this hypoglycaemic effect of the leaf extract was sustained till the end of the study.

\section{Effect of doses of $L$. africana leaf extract on serum hepatic function indices in alloxan-induced diabetic rats}

Table 3 depicts the ameliorative effect of aqueous extract of $L$. africana leaf on AST, ALT, ALP and proteins in serum of alloxan-induced diabetic rats. The activities of 
Table 2. Effect of doses of Lasianthera africana leaf extract on fasting blood glucose in alloxan-induced diabetic rats $(\mathrm{mg} / \mathrm{dl})$.

\begin{tabular}{cccccc}
\hline Treatment groups & Day 0 & Day 7 & Day 14 & Day 21 & Day 28 \\
\hline i & $65.60^{\mathrm{a}} \pm 2.70$ & $76.20^{\mathrm{b}} \pm 1.30$ & $73.40^{\mathrm{b}} \pm 2.41$ & $67.20^{\mathrm{a}} \pm 1.48$ & $67.00^{\mathrm{a}} \pm 2.12$ \\
ii & $235.60^{\mathrm{a}} \pm 3.91$ & $309.40^{\mathrm{b}} \pm 3.05$ & $317.80^{\mathrm{c}} \pm 4.76$ & $346.00^{\mathrm{d}} \pm 3.16$ & $377.80^{\mathrm{e}} \pm 6.14$ \\
iii & $272.20^{\mathrm{a}} \pm 3.03$ & $234.60^{\mathrm{b}} \pm 5.68$ & $198.40^{\mathrm{c}} \pm 4.39$ & $162.80^{\mathrm{d}} \pm 4.21$ & $101.60^{\mathrm{e}} \pm 3.97$ \\
iv & $281.00^{\mathrm{a}} \pm 4.30$ & $262.60^{\mathrm{b}} \pm 5.18$ & $231.60^{\mathrm{c}} \pm 3.05$ & $155.20^{\mathrm{d}} \pm 4.76$ & $108.20^{\mathrm{e}} \pm 5.26$ \\
V & $242.40^{\mathrm{a}} \pm 2.28$ & $215.20^{\mathrm{b}} \pm 3.19$ & $138.40^{\mathrm{c}} \pm 5.32$ & $120.80^{\mathrm{d}} \pm 3.70$ & $87.40^{\mathrm{e}} \pm 4.72$ \\
Vi & $290.60^{\mathrm{a}} \pm 2.70$ & $216.40^{\mathrm{b}} \pm 5.32$ & $219.40^{\mathrm{c}} \pm 4.83$ & $146.40^{\mathrm{d}} \pm 4.34$ & $111.20^{\mathrm{e}} \pm 3.89$ \\
\hline
\end{tabular}

Value are means $\pm S D, n=5$. Means across each row with different superscripts differ significantly $(p<0.05)$. i $=$ normal control; $\mathrm{ii}=$ negative $($ diabetic) control; $\mathrm{iii}=$ diabetic + metformin (positive control); iv $=$ diabetic + extract $(50 \mathrm{mg}) ; \mathrm{v}=$ diabetic + extract $(100 \mathrm{mg}) ; \mathrm{vi}=$ diabetic + extract $(200 \mathrm{mg})$

Table 3. Effect of doses of Lasianthera africana leaf extract on hepatic function indices in alloxan-induced diabetic rats.

\begin{tabular}{cccccccc}
\hline $\begin{array}{c}\text { Treatment } \\
\text { groups }\end{array}$ & $\begin{array}{c}\text { AST } \\
(\mathbf{I U} / \mathbf{L})\end{array}$ & $\begin{array}{c}\text { ALT } \\
(\mathbf{I U} / \mathbf{L})\end{array}$ & $\begin{array}{c}\text { ALP } \\
(\mathbf{I U} / \mathbf{L})\end{array}$ & $\begin{array}{c}\text { Total proteins } \\
\mathbf{( g / d l})\end{array}$ & $\begin{array}{c}\text { Albumin } \\
(\mathbf{g} / \mathbf{d l})\end{array}$ & $\begin{array}{c}\text { Globulin } \\
\text { (g/dl) }\end{array}$ & $\begin{array}{c}\text { Albumin/ } \\
\text { globulin } \\
\text { ratio }\end{array}$ \\
\hline I & $39.09 \pm 0.38$ & $26.50 \pm 0.47$ & $147.80 \pm 2.18$ & $7.00 \pm 0.06$ & $3.75 \pm 0.17$ & $3.25 \pm 0.23$ & 1.15 \\
ii & $65.60^{\mathrm{a}} \pm 0.58$ & $51.64^{\mathrm{a}} \pm 0.74$ & $306.98^{\mathrm{a}} \pm 7.54$ & $5.31^{ \pm} \pm 0.28$ & $2.11^{\mathrm{a}} \pm 0.21$ & $3.20 \pm 0.19$ & 0.66 \\
iii & $49.51^{\mathrm{ab}} \pm 0.58$ & $38.14^{\mathrm{ab}} \pm 0.61$ & $217.32^{\mathrm{ab}} \pm 3.35$ & $6.69^{\mathrm{b}} \pm 0.16$ & $3.83^{\mathrm{b}} \pm 0.33$ & $2.86 \pm 0.48$ & 1.34 \\
iv & $51.74^{\mathrm{abc}} \pm 0.29$ & $36.87^{\mathrm{ab}} \pm 0.29$ & $239.78^{\mathrm{abc}} \pm 3.57$ & $6.21^{1} \pm 0.30$ & $3.35^{\mathrm{b}} \pm 0.31$ & $2.86 \pm 0.17$ & 1.17 \\
v & $42.75^{\mathrm{abc}} \pm 0.25$ & $31.97^{\mathrm{abc}} \pm 0.40$ & $206.74^{\mathrm{ab}} \pm 5.66$ & $6.58^{\mathrm{b}} \pm 0.24$ & $3.55^{\mathrm{b}} \pm 0.26$ & $3.03 \pm 0.03$ & 1.17 \\
vi & $45.39^{\mathrm{abc}} \pm 0.44$ & $28.92^{\mathrm{abc}} \pm 0.50$ & $151.60^{\mathrm{bc}} \pm 3.44$ & $7.10^{\mathrm{b}} \pm 0.21$ & $3.62^{\mathrm{b}} \pm 0.34$ & $3.28 \pm 0.34$ & 1.17 \\
\hline
\end{tabular}

Value are means $\pm S D, n=5$. Means on the same column with different superscripts are significantly different at $(p<0.05)$. a $=p<0.05(T e s t$ groups compared with group I). $\mathrm{b}=\mathrm{p}<0.05$ (Compared with groups II). $\mathrm{c}=\mathrm{p}<0.05$ (Compared with groups III). $\mathrm{i}=$ normal control; ii $=$ negative (diabetic) control; iii = diabetic + metformin (positive control); iv = diabetic + extract $(50 \mathrm{mg}) ; \mathrm{v}=\operatorname{diabetic}+$ extract $(100 \mathrm{mg}) ; \mathrm{vi}=\operatorname{diabetic}+$ extract $(200$ $\mathrm{mg})$.

Table 4. Effect doses of Lasianthera africana leaf extract on renal function indices in alloxan-induced diabetic rats.

\begin{tabular}{ccc}
\hline Treatment groups & Creatinine $\mathbf{( m g / d l})$ & Uric acid $(\mathbf{m g} / \mathbf{d l})$ \\
\hline I & $0.51 \pm 0.02$ & $3.81 \pm 1.17$ \\
ii & $0.68^{\mathrm{a}} \pm 0.02$ & $4.29 \pm 0.16$ \\
iii & $0.53^{\mathrm{b}} \pm 0.07$ & $3.76 \pm 0.29$ \\
iv & $0.59 \pm 0.04$ & $3.10 \pm 0.22$ \\
v & $0.61 \pm 0.04$ & $3.83 \pm 30.32$ \\
vi & $0.57 \pm 0.02$ & $3.73 \pm 0.25$ \\
\hline
\end{tabular}

Values are means $\pm S D, n=5$. Means on the same column with different superscripts are significantly different at $\mathrm{P}<0.05$. $\mathrm{a}=\mathrm{p}<$ 0.05 (Test groups compared with $\mathrm{I}$ ). $\mathrm{b}=\mathrm{p}<0.05$ (Compared with groups II). $\mathrm{i}=$ normal control; $\mathrm{ii}=$ negative (diabetic) control; $\mathrm{iii}=$ diabetic + metformin (negative control); iv = diabetic + extract $(50$ $\mathrm{mg}) ; \mathrm{v}=$ diabetic + extract $(100 \mathrm{mg}) ; \mathrm{vi}=$ diabetic + extract $(200 \mathrm{mg})$.

AST, ALT and ALP were significantly $(p<0.05)$ elevated in the diabetic control rats relative to normal control rats. Treatment of alloxan-induced diabetic rats with doses $(50,100$ and $200 \mathrm{mg} / \mathrm{kg}$ body weight) of $L$. africana leaf extract caused significant $(p<0.05)$ reduction in AST by
$21.13,34.83$ and $30.81 \%$, in ALT by $28.60,38.09$ and $44.00 \%$ and in ALP by 21.89, 32.65 and $50.60 \%$, respectively. The diabetic control rats showed marked proteins metabolic disturbances evident from their significant $(p<0.05)$ lower total protein $(24.14 \%)$ and albumin $(43.73 \%)$ compared to the normal control group. Treatment of diabetic rats with doses of the leaf extract for 28 days significantly $(p<0.05)$ increased the serum total proteins by $16.99,23.92$ and $33.71 \%$ and albumin by $58.77,68.25$ and $81.04 \%$ for 50,100 and $200 \mathrm{mg} / \mathrm{kg}$ body weight doses, respectively, compared to diabetic control rats. The albumin to globulin ratio of the diabetic control group was lower than those of the normal control and diabetic treated groups (Table 3).

\section{Effect of doses of $L$. africana leaf extract on serum renal function indices in alloxan-induced diabetic rats}

Table 4 shows the effect of oral administration of doses of $L$. africana leaf extract on serum creatinine and uric acid in alloxan-induced diabetic rats. The result shows that untreated diabetic rats (diabetic control) had significantly $(p<0.05)$ higher serum creatinine content and marginally 
( $p>0.05$ ) higher uric acid content than the normal control group. Treatment of alloxan-induced diabetic rats with $L$. africana leaf extract (oral administration) for 28 days with daily doses of 50,100 and $200 \mathrm{mg} / \mathrm{kg}$ body weight resulted in reductions $(p>0.05)$ of serum creatinine levels by 10.29 , 13.24 and $16.18 \%$ and uric acid by $8.50,18.85$ and $10.78 \%$, respectively, compared to the untreated diabetic rats.

\section{DISCUSSION}

The results of acute toxicity study indicate that $L$. africana leaf extract administered by oral route with the dose up to $5,000 \mathrm{mg} / \mathrm{kg}$ body weight did not produce any sign of toxicity or death in rats at the end of the 14 day observations. Weight loss which is a single and sensitive index of toxicity after exposure to toxic substances (Raza et al., 2002; Teo et al., 2002) were not observed in any of the treatment groups (Table 1). Based on the aforementioned observations, $L$. africana leaf extract can be considered non-toxic at the levels they were used. According to Kennedy et al. (1986), substances whose $\mathrm{LD}_{50}$ is higher than $5,000 \mathrm{mg} / \mathrm{kg}$ body weight by oral route can be considered practically nontoxic. In agreement with the results obtained in this study, Ikewuchi and Ikewuchi (2012) reported significant $(p<0.05)$ increase in fasting blood glucose in alloxan-induced diabetic untreated rats. The reduction of fasting blood glucose in alloxan-induced diabetic rats as a result of daily oral administration of $L$. africana leaf extract (Table 2) signifies the hypoglycaemic potential of the extract. The most effective dose of the leaf extract was $100 \mathrm{mg} / \mathrm{kg}$ body weight as it produced $63.97 \%$ reduction in fasting blood glucose on day 28 compared to 61.50 and $61.73 \%$ reductions for groups that received daily dose of 50 and $200 \mathrm{mg} / \mathrm{kg}$ body weight, respectively. Similar low hypoglycaemic response at higher dose administration of some plant products have been reported by Kesari et al. (2005) and Mowla et al. (2009) for Murraya Koenigii and Trigonella foenumgraecum seed extract, respectively. The hypoglycaemic effect of the leaf extract compared favourably with the commercial anti-diabetic drug (metformin) that showed $62.68 \%$ fasting blood glucose reduction on the last day of the experiment. The active constituents responsible for hypoglycaemic effect in some plants have been identified to include diterpenes, flavonoids, alkaloids and steroidal glycosides among others (Akah et al., 2002; Li et al., 2004). These constitutents have been identified in $L$. africana leaf (Bassey et al., 2006) and may probably be responsible for the observed hypoglycaemic effect of the leaf extract. This result suggests that the extract of $L$. africana leaf can be used in the management of diabetes mellitus.

According to Hilaly et al. (2004), AST, ALT and ALP are considered markers for liver function. Elevation of these enzymes in serum serves as an indicator of hepatotoxicity (Elizabeth and Harris, 2005). AST and ALT are usually found in large quantities in the liver where they play an important role in the metabolism of amino acid (Whitehead et al., 1999). ALP on the other hand is predominantly found in the bile duct of the liver, and is considered as an indicator of biliary function, cholestasis and hepatic function (Whitehead et al., 1999; Elizabeth and Harris, 2005). The elevated levels of AST, ALT and ALP in the serum of diabetic control rats (Table 3 ) suggest hepatocellular damage which could cause their leakage from the hepatocytes into the blood circulation (Elizabeth and Harris, 2005). Stanely et al. (2000) noted that experimental diabetes induced by alloxan in rats cause tissue damage in the pancreas, liver, kidneys and heart, which can be reflected by an increase of AST and various hepatic enzymes such as ALT. The result of this study corroborate those of other authors who also reported increased AST, ALT and ALP in serum of alloxan-induced diabetic rats (Moram, 2001; Nwanjo, 2007; Akah et al., 2009; Ikewuchi and Ikewuchi, 2012). Similar decreases in AST, ALT and ALP in the serum of alloxan-induced diabetic rats following treatments with various plant extracts had been reported by Moram (2001), Nwanjo (2007), Akah et al. (2009) and Ikewuchi and Ikewuchi (2012). The result of this study indicates that $L$. africana leaf extract contained constituents that exerted hepatoprotective effect in alloxan-induced diabetic rats. The actual mechanism by which the leaf extract reduced elevated serum levels of AST, ALT and ALP in alloxaninduced rats remains unclear. Rawi et al. (1998) noted that the decrease of transaminase activities with treatments may be attributed to improved liver function with the return of gluconeogenesis towards its normal state. Determination of serum protein like albumin can act as a criterion for assessing synthetic capacity of the liver, since nearly all of them are synthesized in hepatocytes (Rasekh et al., 2008). Decreases in serum proteins as observed in diabetic control rats (Table 3 ) reflects chronic liver damage. Similar observation was reported by Akah et al. (2009). The common pattern seen following significant hepatocellular damage is a reduction in albumin accompanied by a relative increase in globulin which leads to reduce albumin to globulin ratio (Woodman, 1996). The implication of this result is that $L$. africana leaf extract has potentials to prevent hepatocellular damage in diabetic animals.

In the present study, creatinine and uric acid determinations were critical as markers of kidney function (Newman and Price, 1999). Creatinine is excreted out of the body entirely by the kidneys while uric acid is excreted to a large degree by the kidneys and to a smaller degree in the intestinal tract by microbial degradation (Sood, 2006). Elevated creatinine and uric acid levels in the serum of untreated diabetic rats signify impaired kidney function or disease (Sood, 2006). Similar higher levels of serum creatinine and uric acid in alloxaninduced diabetic rats had been reported by Akah et al. (2009) and Alarcon - Aguilar et al. (2005), respectively. 
Reductions of serum creatinine and uric acid levels as a result of treatment with the extract indicate that the leaf extract exhibited potentials to preserve the renal integrity of the treated rats. The observed apparent kidney protection exhibited by the leaf extract may be associated with the inherent heterogeneous phytochemicals present naturally in the leaf. Reduction of uric acid in the treated rats suggest that therapeutic advantage can be taken of the leaf extract ability to reduce uric acid in hyperuricemia, a condition that can pre-dispose to gouty arthritis, intense inflammation of soft tissues on which urate crystals are deposited (Rock et al., 1986).

\section{Conclusion}

The results obtained herein indicate that $L$. africana leaf extract administered by oral route is safe. The study shows that the extract was hypoglycaemic and also revealed the hepato-renal protective potentials of the extract in alloxan-induced diabetic rats. Further biochemical investigations are proposed to elucidate the mechanism of action of this extract.

\section{Conflict of interests}

The authors did not declare any conflict of interest.

\section{REFERENCES}

Achukwu PUO, Azubike NC, Okwuosa CN, Onu TO (2009). Toxicological study of the aqucous leaf extract of Mucuna flagellipes on albino wister rats. Afr. J. Sci. 10(1):2293-2303.

Akah PA, Alemji JA, Salawu OA, Okoye TC, Offiah NV (2009). Effect of Vernonia amygdalina on biochemical and haematological parameters of diabetic rats. Asian J. Med. Sci. 1(3):108-113.

Akah PA, Okoli CO, Nwafor SV (2002). Phytotherapy in the management of diabetes mellitus. J. Nat. Rem. 2:1-10.

Alarcon-Aguilar FJ, Calzada-Bermajo F, Hernandez-Galicia E, RuizAngeles C, Roman-Ramos R (2005). Acute and chronic hypoglycaemic effect of Ibervillea sonorae root extract - II. J. Ethnopharmacol. 97:447-452.

Andy IE, Eja ME, Mboto $\mathrm{Cl}$ (2008). An evaluation of the antimicrobial potency of Lasianthera africana (Beauv) and Heinsia crinata (G. Taylor) on Escherichia coli, salmonella typhi, staphylococcusaureus and candida albicans. Malays. J. Microbiol. 4(1):25-29.

Angelis Pereira MC, Carvalho JCT, Lima LM, Caputo LRG, Ferreira LR, Fiorini JE, Baston JK (2003). Toxicity of a sub-chronic treatment with hydroalcoholic crude extract from Solanum grandiflorum (Ruiz Pav) in rats. J. Ethnopharmacol. 89:97-99.

Antai AB, Ofem OE, Nwosu OJ, Ukafia SO, lyadi KC, Nia R, Osim EE (2010). Comparative effects of Rothmannia hispida leaves extract and protamine-zinc insulin on alloxan-induced diabetic rats. Afr. J. Biomed. Res. 13:47-54.

Bassey ME, Etuk EUI, Ubom R, Obop IE (2006). Chemotaxonomic study of Lasianthera africana (Icacinaceae) in Akwa Ibom State of Nigeria. Nig. J. Bot. 19:99-102.

Ebana RU, Essien AI, Ekpo OD (1996). Potential medicinal value of leaves of Lasianthera africana P. Beav. Glob. J. Pure Appl. Sci. 1:27.

Elizabeth $\mathrm{H}$, Harris MD (2005). Elevated liver function tests in type 2 diabetes. Clin. Diabetes 23:115-119.

Etukudo I (2003). Ethnobotany conventional and traditional uses of plants. Verdict Press, Uyo. pp. 12-65.

Hilaly J, El Israili ZH, Lyoussi B (2004). Acute and chronic toxicological studies of Ajuga iva in experimental animals. J. Ethnopharmacol. 91: 43-50.

Homburger $F$ (1989). In-vitro testing in the study of toxicity and safety evaluation. In: A guide to general toxicity. ( $2^{\text {nd }}$ revised edn). Judith $\mathrm{K}$. Marguis (ed), Karger, New York, pp. 196-207.

Hutchinson J, Dalziel JM (1973). Flora of West Tropical Africa $\left(2^{\text {nd }}\right.$ edn.), Crown Agents, London, p. 638.

Ikewuchi JC, Ikewuchi CC (2012). Hypoglycemic, hypocholesterolemic ocular-protective effect of an aqueous extract of the Rhizomes of Sunsevieria senegambia Baker (Agavaccac) on alloxan-induced diabetic Wister rats. Am. J. Biochem. Mol. Biol. 2:48-66.

Kennedy GL, Ferenz RL, Burgess BA (1986). Estimation of acute oral toxicity in rats by determination of the approximate lethal dose rather than the LD $D_{50}$. J. Appl. Toxicol. 6:145-148.

Kesari AN, Gupta RK, Watal G (2005). Hypoglycemic effect of Murraya koenigii on normal and alloxan-diabetic rabbits. J. Ethnopharmacol. 97:247-251.

Li WL, Zheng HC, Bukuru J, De Kimpe N (2004). Natural medicines used in the traditional Chinese medical system for therapy of diabeties mellitus. J. Ethnopharmacol. 92:1-21.

Lorke D (1983). A new approach to acute toxicity testing. Arch. Toxicol. 54:275-287.

Moram GS (2001). Effect of aqueous extracts from some plants on alloxan-diabetic rats. Egypt. J. Hosp. Med. 2:57-69.

Mowla A, Alauddin M, Rahman MA, Ahmed K (2009). Antihyperglycaemic effect of Trigonella foe numgraecum (Fenugreek) seed extract in alloxan-induced diabetic rats and its use in diabetes mellitus: A brief qualitative phytochemical and acute toxicity test on the extract. Afr. J. Trad. Cam. 6(3):255-261.

Newman DJ, Price CP (1999). Renal function and nitrogen metabolites. In: Burtis CA, Ashwood ER (Eds.). Tietz textbook on clinical chemistry. W. B. Saunders Company, Philadelphia, pp. 1204-1270.

$\mathrm{NIH}$ Publication (1985). Respect for life. National Institute of Environmental Health Science. Pub. No. 85-23.

Nwanjo HU (2007). Studies on the effect of aqueous extract of Phyllanthus niruri on plasma glucose level and some hepatospecific markers in diabetic Wister rats. Int. J. Lab. Med. 2(2):1-18.

Rasekh HR, Nasari P, Kamli-Leila M, Hosseinzadeh L (2008). Acute and sub-chronic oral toxicity of Galega officinalis in rats. J. Ethnopharmacol. 116:21-26.

Rawi SM, Abdel-Moneim A, Ahmed OM (1998). Studies on the effect of garlic oil and the glibenclamide on alloxan-diabetic rats. Egypt $\mathrm{J}$ Zool. 30:211-228.

Raza M, Al-Shabanah OA, El-Hadiyah TM, Al-Majed AA (2002). Effect of prolonged vigabatrim treatment on haematological and biochemical parameters in plasma, kidney and liver of Swiss Albino mice. Sci. Pharm. 70:135-145.

Rock RC, Walker G, Jennings D (1986). Nitrogen metabolites and renal functions. In: Tietz NW (ed). Textbook of clinical chemistry. W. B Saunders Company, London, pp. 1254-1316.

Sofowora A (1989). Medicinal plants and traditional medicine in Africa. John Wiley and sons Ltd. London. pp. 12-146.

Sood R (2006). Textbook of medical laboratory technology. Jaypee Brothers medical Publishers Ltd., New Delhi, pp. 196-210, 598-690.

Stanely P, Mainzen P, Venugopal PM (2010). Hypoglycaemic and other related actions of Tinospora cordifolia roots in alloxan-induced diabetic rats. J. Ethnopharmacol. 70:9-15.

Tang L, Wei W, Chen L, Liu S (2006). Effect of berberina on diabetes induced by alloxan and a high-fat/high-cholesterol diet in rats. J. Ethnopharmcol. 108:109-115.

Teo S, Stirling D, Thomas S, Hoberman A, Kiorpes A, Khetani V (2002). A 90-day oral gavage toxicity of D-methylphenidate and D, Lmathylphenidate in Sprague-Dawley rats. Toxicology 179:183-196.

Whitehead MW, Hawkes ND, Hainsworth I, Kingham JG (1999). A prospective study of the causes of notably raised aspartate aminotransferase of liver origin. Gut 45:129-133.

WHO (1980). WHO Expert Committee on Diabetes Mellitus Technical report series. World Health Organization, Geneva.

Williams IO, Parker RS, Swanson J (2009). Vitamin A content of South Eastern Nigerian vegetable dishes, their consumption pattern and 
contribution to vitamin A requirement. Pak. J. Nutr. 8(7): 1000-1004.

Wilson NH, Hardisty JF, Hayes JR (2001). Short-term, sub-chronic and chronic toxicity studies. In: A. W. Hayes (ed). Principles and methods of Toxicology. Taylor and Francis, Philadelphia. pp. 917-956.
Woodman DD (1996). Assessment of hepatotoxicity. In: GO Evans (ed); Animal clinical chemistry, A Premer for Toxicologists. Taylor and Francis, London, pp. 71-86. 